\title{
JBIR-17, a novel trichostatin analog from Streptomyces sp. 26634
}

\author{
Jun-ya Ueda ${ }^{1}$, Ji-Hwan Hwang ${ }^{2}$, Satoko Maeda ${ }^{3}$, Taira Kato ${ }^{4}$, Atsushi Ochiai ${ }^{4}$, Kunio Isshiki ${ }^{4}$, \\ Minoru Yoshida ${ }^{3}$, Motoki Takagi ${ }^{1}$ and Kazuo Shin-ya ${ }^{2}$
}

The Journal of Antibiotics (2009) 62, 283-285; doi:10.1038/ja.2009.22; published online 20 March 2009

Keywords: histone deacetylase; histone deacetylase inhibitor; Streptomyces; trichostatin

Histone deacetylases (HDACs) play an important role in the epigenetic regulation of gene expression by catalyzing the removal of acetyl groups from lysine residue of histone protein, stimulating chromatin condensation and promoting transcriptional repression. ${ }^{1,2}$ HDACs are divided into four classes on the basis of their homology to yeast HDACs: class I (HDAC1, 2, 3 and 8), class IIa (HDAC4, 5, 7 and 9), class IIb (HDAC6 and 10), class III (SIRT1, 2, 3, 4, 5, 6 and 7) and class IV (HDAC11). As aberrant epigenetic changes are a hallmark of cancer, HDACs are a promising target for an anticancer drug. The inhibitors of HDACs can induce cell-cycle arrest, promote differentiation and stimulate tumor cell death. In fact, several HDAC inhibitors are currently in clinical trials both for solid and hematological malignancies. ${ }^{1,2}$ Therefore, we attempted to search new HDAC inhibitors. As a result, we isolated a novel compound designated as JBIR17 (1) from Streptomyces sp. 26634 (Figure 1). We report herein the isolation, structure elucidation and biological activity of $\mathbf{1}$.

Streptomyces sp. 26634 was isolated from a leaf of Kerria japonica collected in Iwata, Shizuoka Prefecture, Japan, and cultured on a rotary shaker (220 r.p.m.) at $28^{\circ} \mathrm{C}$ for 4 days in a $500-\mathrm{ml}$ Erlenmeyer flask containing $60 \mathrm{ml}$ of a medium consisting of $4 \% \beta$-cyclodextrin, $0.5 \%$ glycerol, $2 \%$ Pharmamedia (Traders Protein, Lubbock, TX, USA), $0.0005 \% \mathrm{CuSO}_{4} \cdot 5 \mathrm{H}_{2} \mathrm{O}, 0.0005 \% \mathrm{MnCl}_{2} \cdot 4 \mathrm{H}_{2} \mathrm{O}$ and $0.0005 \%$ $\mathrm{ZnSO}_{4} \cdot 7 \mathrm{H}_{2} \mathrm{O}$.

$n$ - $\mathrm{BuOH}(37.5 \mathrm{ml})$ was added to the fermentation broth $(60 \mathrm{ml})$ and shaken for $15 \mathrm{~min}$. After centrifugation, the organic layer was evaporated in vacuo. The dried residue $(107 \mathrm{mg})$ was subjected to reversed-phase medium-pressure liquid chromatography (Purif-Pack ODS 100, Moritex, Tokyo, Japan) and eluted with a $\mathrm{MeOH}-\mathrm{H}_{2} \mathrm{O}$ (5$100 \% \mathrm{MeOH})$ linear gradient system. The $70-90 \% \mathrm{MeOH}$ eluate $(3.7 \mathrm{mg})$ was further purified by reversed-phase HPLC using an
XBridge Prep $\mathrm{C}_{18}$ column ( $5 \mu \mathrm{m}$ optimum bed density (OBD), 4.6 i.d. $\times 250 \mathrm{~mm}$, Waters, Milford, MA, USA) with $35 \%$ aqueous $\mathrm{CH}_{3} \mathrm{CN}$ containing $0.2 \%$ formic acid (flow rate, $1 \mathrm{ml} \mathrm{min}^{-1}$ ) to yield JBIR-17 (1, $0.9 \mathrm{mg}$; retention time (Rt) $9.7 \mathrm{~min})$ and trichostatin $\mathrm{A}(2,0.7 \mathrm{mg}$; Rt $10.3 \mathrm{~min}) .^{3}$

The physicochemical properties of $\mathbf{1}$ are summarized in Table 1. Compound 1 was obtained as a colorless amorphous solid, and its molecular formula was determined to be $\mathrm{C}_{20} \mathrm{H}_{26} \mathrm{~N}_{2} \mathrm{O}_{5}$ by HR-electrospray ionization (ESI)-MS. The IR spectrum revealed the characteristic absorptions of the aroyl and/or amide carbonyl $\left(v_{\max } 1652 \mathrm{~cm}^{-1}\right)$ and amide N-H $\left(v_{\max } 1597 \mathrm{~cm}^{-1}\right)$ groups. The structure of 1 was mainly determined by NMR spectral analyses as follows.

The direct connectivity between each proton and carbon was established by the heteronuclear single quantum coherence spectrum, and the ${ }^{13} \mathrm{C}$ and ${ }^{1} \mathrm{H}$ NMR spectral data for $\mathbf{1}$ are shown in Table 2 . A total of 20 signals were observed in the ${ }^{13} \mathrm{C}$ NMR spectrum, consistent with the HR-MS data. These signals included three carbonyl (C-1, C-7, C-1'), four olefinic (C-2 to C-5) and six aromatic (C-8 to C-13) carbons. The proton spin couplings between two olefinic protons $2-\mathrm{H}$ $\left(\delta_{\mathrm{H}} 5.91\right)$ and $3-\mathrm{H}\left(\delta_{\mathrm{H}} 7.28\right)$, between an olefinic proton $5-\mathrm{H}\left(\delta_{\mathrm{H}}\right.$ $6.04)$ and a methyl proton $6-\mathrm{Me}\left(\delta_{\mathrm{H}} 1.28\right)$ through a methine proton $6-\mathrm{H}\left(\delta_{\mathrm{H}} 4.36\right)$, and between two equivalent aromatic protons $9,13-\mathrm{H}$ $\left(\delta_{\mathrm{H}} 7.84\right)$ and $10,12-\mathrm{H}\left(\delta_{\mathrm{H}} 6.69\right)$ on a $p$-disubstituted benzene ring were observed in a double-quantum filtered (DQF)-COSY spectrum as shown in Figure 2 (bold line). The constant time heteronuclear multibond correlation (CT-HMBC) experiment revealed the presence of ${ }^{1} \mathrm{H}-{ }^{13} \mathrm{C}$ long-range couplings from an $\mathrm{N}, \mathrm{N}$-dimethyl proton $\left(\delta_{\mathrm{H}}\right.$ $3.05)$ to an aromatic carbon $\mathrm{C}-11\left(\delta_{\mathrm{C}} 155.2\right)$, from $9,13-\mathrm{H}$ to $\mathrm{C}-11$ and a carbonyl carbon $\mathrm{C}-7\left(\delta_{\mathrm{C}} 198.7\right)$, from $10,12-\mathrm{H}$ to an aromatic carbon $\mathrm{C}-8\left(\delta_{\mathrm{C}} 127.0\right)$, from $6-\mathrm{Me}, 6-\mathrm{H}$ and $5-\mathrm{H}$ to $\mathrm{C}-7$, from the

${ }^{1}$ Biomedicinal Information Research Center (BIRC), Japan Biological Informatics Consortium (JBIC), Koto-ku, Tokyo, Japan; ${ }^{2 B i o m e d i c i n a l ~ I n f o r m a t i o n ~ R e s e a r c h ~ C e n t e r ~(B I R C), ~}$ National Institute of Advanced Industrial Science and Technology (AIST), Koto-ku, Tokyo, Japan; ${ }^{3}$ Chemical Genomics Research Group/Chemical Genetics Laboratory, RIKEN Advanced Science Institute, Wako, Saitama, Japan and ${ }^{4}$ Bioresource Laboratories, Mercian Corporation, Iwata, Shizuoka, Japan

Correspondence: Dr M Takagi, Biomedicinal Information Research Center (BIRC), Japan Biological Informatics Consortium (JBIC), 2-42 Aomi, Koto-ku, Tokyo 135-0064, Japan. E-mail: motoki-takagi@aist.go.jp or

Dr K Shin-ya, Biomedicinal Information Research Center (BIRC), National Institute of Advanced Industrial Science and Technology (AIST), 2-42 Aomi, Koto-ku, Tokyo 135-0064, Japan.

E-mail: k-shinya@aist.go.jp

Received 4 February 2009; revised 26 February 2009; accepted 27 February 2009; published online 20 March 2009 
<smiles>CC(/C=C/C(=O)N[C@H](CO)C(=O)O)=C\[C@@H](C)C(=O)c1ccc(N(C)C)cc1</smiles><smiles>CC(/C=C/C(=O)NO)=C\[C@@H](C)C(=O)c1ccc(N(C)C)cc1</smiles>

Figure 1 Structures of JBIR-17 (1) and trichostatin A (2).

\section{Table 1 Physicochemical properties of 1}

\begin{tabular}{ll}
\hline Appearance & Colorless amorphous solid \\
Optical rotation & \\
HR-ESI-MS & {$[\alpha]_{D}^{25}-18.0^{\circ}(c 0.1, \mathrm{MeOH})$} \\
$\quad$ Found & \\
$\quad$ Calculated & $375.1880(\mathrm{M}+\mathrm{H})^{+}$ \\
$U \mathrm{VV}^{\mathrm{c}} \lambda_{\max } \mathrm{nm}(\varepsilon)$ & $375.1920\left(\mathrm{C}_{20} \mathrm{H}_{27} \mathrm{~N}_{2} \mathrm{O}_{5}\right)$ \\
$\mathrm{IR}^{\mathrm{d}}(\mathrm{KBr}) v_{\max } \mathrm{cm}^{-1}$ & $264(24700), 336(23500)$ \\
\end{tabular}

Abbreviation: ESI, electrospray ionization.

aOptical rotation was measured on a SEPA-300 polarimeter (Horiba, Kyoto, Japan).

bHR-ESI-MS measurement was carried out on a LCT Premier XE mass spectrometer (Waters).

CUV spectrum was measured on a COULTER DU730 UV/Nis Spectrophotometer (Beckman,

Fullerton, CA, USA).

dIR spectra was obtained on a FT-720 Fourier transform infrared spectrometer (Horiba).

Table $2{ }^{13} \mathrm{C}$ and ${ }^{1} \mathrm{H}$ NMR data for 1

\begin{tabular}{|c|c|c|}
\hline Position & $\delta_{C}$ & $\delta_{H}$ \\
\hline 1 & 168.6 & \\
\hline 2 & 117.5 & $5.91(d, 15.4)$ \\
\hline 3 & 147.5 & $7.28(d, 15.4)$ \\
\hline 4 & 132.5 & \\
\hline 5 & 141.9 & $6.04(d, 9.5)$ \\
\hline 6 & 40.9 & $4.36(\mathrm{dq}, 9.5,6.9)$ \\
\hline 7 & 198.7 & \\
\hline 8 & 127.0 & \\
\hline 9,13 & 130.7 & $7.84(\mathrm{~d}, 8.8)$ \\
\hline 10,12 & 111.2 & $6.69(d, 8.8)$ \\
\hline 11 & 155.2 & \\
\hline $1^{\prime}$ & 172.0 & \\
\hline $2^{\prime}$ & 54.8 & 4.60 (br s) \\
\hline $3^{\prime}$ & 62.1 & 4.18 (br d, 10.5); 3.85 (br d, 10.5) \\
\hline 4-methyl & 12.6 & $1.89(\mathrm{~s})$ \\
\hline 6-methyl & 17.8 & $1.28(\mathrm{~d}, 6.9)$ \\
\hline $11 \mathrm{~N}, \mathrm{~N}$-dimethyl & 40.3 & 3.05 (s) \\
\hline
\end{tabular}

${ }^{13} \mathrm{C}(125 \mathrm{MHz})$ and ${ }^{1} \mathrm{H}(500 \mathrm{MHz}) \mathrm{NMR}$ spectra were taken on a NMR System $500 \mathrm{NB} \mathrm{CL}$ (Varian, Palo Alto, $\mathrm{CA}, \mathrm{USA}$ ) in $\mathrm{CDCl}_{3}$, and the solvent peak was used as an internal standard $\left(\delta_{\mathrm{C}} 77.0, \delta_{\mathrm{H}} 7.26\right)$.

vinyl methyl proton $4-\mathrm{Me}\left(\delta_{\mathrm{H}} 1.89\right)$ to three olefinic carbons $\mathrm{C}-3\left(\delta_{\mathrm{C}}\right.$ 147.5), C-4 $\left(\delta_{\mathrm{C}} 132.5\right)$ and $\mathrm{C}-5\left(\delta_{\mathrm{C}} 141.9\right)$, and from $2-\mathrm{H}$ and $3-\mathrm{H}$ to an amide carbonyl carbon $\mathrm{C}-1\left(\delta_{\mathrm{C}} 168.6\right)$. The stereochemistries of

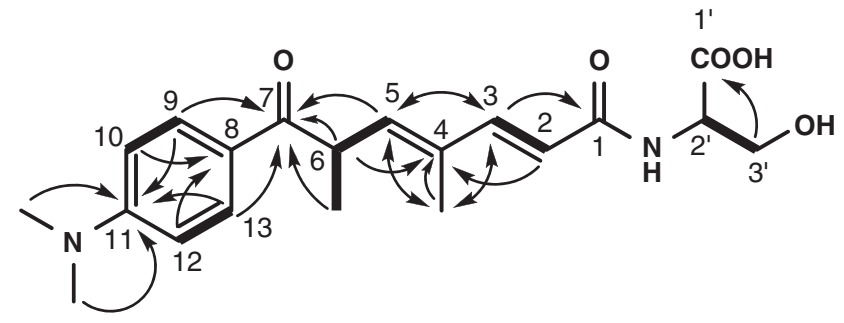

Figure 2 Key correlations in DQF-COSY (bold line) and CT-HMBC (arrow) spectra of 1 .

two olefins were determined as $2 E$ and $4 E$ according to the coupling constant $\left(J_{2,3}=15.4 \mathrm{~Hz}\right)$ and the high-field-shifted ${ }^{13} \mathrm{C}$ chemical shift at $4-\mathrm{Me}\left(\delta_{\mathrm{C}} 12.6\right)$. Thus, the partial structure was elucidated as a trichostatic acid (3) moiety, and their ${ }^{13} \mathrm{C}$ and ${ }^{1} \mathrm{H}$ NMR signals are superimposable with those of $2^{3}$ and $3^{4}$.

Additional substructure was elucidated as follows. A proton spin coupling between an $\alpha$-methine proton $2^{\prime}-\mathrm{H}\left(\delta_{\mathrm{H}} 4.60 ; \delta_{\mathrm{C}} 54.8\right)$ and oxymethylene protons $3^{\prime}-\mathrm{H}\left(\delta_{\mathrm{H}} 4.18,3.85 ; \delta_{\mathrm{C}} 62.1\right)$ was observed. A long-range coupling from $3^{\prime}-\mathrm{H}$ to a carboxylic carbonyl carbon $\mathrm{C}-1^{\prime}$ deduced that the remaining structure was a serine moiety, and the serine was assumed to attach to C- 1 of trichostatin through an amide bond.

The linkage position and the absolute configuration of the serine moiety of 1 were confirmed as follows. To determine the absolute configuration of the serine moiety, Marfey's method was adopted. Compound $1(0.8 \mathrm{mg})$ was hydrolyzed with $6 \mathrm{~N} \mathrm{HCl}(0.2 \mathrm{ml})$ at $120^{\circ} \mathrm{C}$ overnight to obtain the serine residue. After acid hydrolysis, the reaction solution was adjusted to neutral $\mathrm{pH}$ and evaporated in vacuo. The residue was dissolved in an aqueous solution of $0.1 \mathrm{M}$ $\mathrm{NaHCO}_{3}(0.6 \mathrm{ml})$, and $10 \mathrm{~mm} \quad N^{\alpha}$-(5-fluoro-2,4-dinitrophenyl)-Lalaninamide (FDAA) in $\mathrm{Me}_{2} \mathrm{CO}(0.6 \mathrm{ml})$ was successively added. The mixture was kept at $70^{\circ} \mathrm{C}$ for $10 \mathrm{~min}$ with frequent shaking. After work-up with the addition of $0.2 \mathrm{~N} \mathrm{HCl}$, the filtered reaction mixture was subjected to ultra performance liquid chromatography (UPLC) analysis (Acquity UPLC BEH $\mathrm{C}_{18} 1.7 \mu \mathrm{m}, 2.1 \times 50 \mathrm{~mm}$, Waters; $10 \%$ aqueous $\mathrm{CH}_{3} \mathrm{CN}$ containing $0.1 \%$ formic acid; flow rate, $\left.0.3 \mathrm{ml} \mathrm{min}^{-1}\right)$. The authentic $\mathrm{D}$ - and $\mathrm{L}$-serine were reacted with FDAA in the same manner as described above. The serine residue obtained from the hydrolysate was determined to be L-serine (Rt $8.6 \mathrm{~min}$; L-Ser, $8.5 \mathrm{~min}$; D-Ser, $9.8 \mathrm{~min}$ ). To confirm the linkage position of serine moiety, $\mathbf{1}$ was semi-synthesized from $\mathbf{2}$ as shown in Figure 3. Briefly, $2(7.5 \mathrm{mg})$ was converted to $3(3.4 \mathrm{mg})$ by $\mathrm{HClO}_{4}$. Compound 3 was coupled with an $O$-t-butyl-L-serine $t$-butyl ester in the presence of PyBOP and $N, N$-diisopropylethylamine followed by deprotection in acidic condition to yield an L-serine adduct of $\mathbf{3}$ $(0.9 \mathrm{mg})$. This synthetic compound showed an identical ${ }^{1} \mathrm{H}$ NMR spectrum to that of naturally isolated 1 from Streptomyces sp. 26634.

To evaluate inhibitory activity for HDACs of $\mathbf{1}$, we used the reporter gene assay system using a luciferase gene as described earlier. ${ }^{5,6}$ The human embryonic kidney $293 \mathrm{~T}$ cells, transformed with the luciferase reporter gene driven by the cytomegalovirus promoter, produced 2.5 times more luciferase compared with the untreated control, when they were treated with 1 at a concentration of $30 \mu \mathrm{M}$. Furthermore, to clarify the selectivity against HDAC subtypes, 1 was tested in the HDAC inhibitory activity using HDAC1 (class I), 4 (class IIa) and 6 (class IIb) enzymes of $293 \mathrm{~T}$ cell origin, which are usually used as the representative HDACs among each HDAC subtype. ${ }^{7}$ Compound 1 showed inhibitory activity against HDAC4 and 6 with $\mathrm{IC}_{50}$ values of 69 and $4.7 \mu \mathrm{M}$, respectively, but no activity against HDAC1 at a 
<smiles>CC(C=CC(=O)O)=C[C@@H](C)C(=O)c1ccc(N(C)C)cc1</smiles>

Figure 3 Scheme of chemical conversion from 2 to 1 . (a) $1.5 \mathrm{~N} \mathrm{HClO}_{4}$ aq, $50^{\circ} \mathrm{C}$, overnight. (b) $O$-t-butyl-L-serine $t$-butyl ester, PyBOP, $N, N$-diisopropylethylamine in $\mathrm{CH}_{2} \mathrm{Cl}_{2} / \mathrm{DMF}$ ( $\mathrm{N}, \mathrm{N}$-dimethylformamide), room temperature, $2 \mathrm{~h}$. (c) $90 \%$ aqueous trifluoroacetic acid, room temperature, $1.5 \mathrm{~h}$.

concentration of $100 \mu \mathrm{M}$. In contrast, 2 showed strong, but not selective, inhibitory effects against these HDACs ( $\mathrm{IC}_{50}$ values, 18, 30 and $92 \mathrm{~nm}$ against HDAC1, 4 and 6, respectively) as reported earlier. 8,9 These results indicated that $\mathbf{1}$ selectively inhibited HDAC6 compared with HDAC1 and 4. HDAC6 is a cytoplasmic enzyme that regulates many important biological processes, including cell migration, immune synapse formation, viral infection and the degradation of misfolded proteins. Furthermore, HDAC6 deacetylates tubulin, Hsp90 and cortactin. ${ }^{10-12}$ The diverse functions of HDAC6 suggest that it is a potential therapeutic target for a wide range of diseases. Thus, JBIR-17 could be a valuable tool for the studies of HDAC6 and enzymatic property among HDAC subtypes.

\section{ACKNOWLEDGEMENTS}

This work was supported in part by the New Energy and Industrial Technology Development Organization of Japan (NEDO), and a Grant-in-Aid for Scientific Research (20380070 to KS) from the Japan Society for the Promotion of Science (JSPS).

1 Carew, J. S., Giles, F. J. \& Nawrocki, S. T. Histone deacetylase inhibitors: mechanisms of cell death and promise in combination cancer therapy. Cancer Lett. 269, 7-17 (2008).

2 Shankar, S. \& Srivastava, R. K. Histone deacetylase inhibitors: mechanisms and clinical significance in cancer: HDAC inhibitor-induced apoptosis. Adv. Exp. Med. Biol. 615, 261-298 (2008).

3 Tsuji, N., Kobayashi, M., Nagashima, K., Wakisaka, Y. \& Koizumi, K. A new antifungal antibiotic, trichostatin. J. Antibiot. 29, 1-6 (1976).

4 Tsuji, N. \& Kobayashi, M. Trichostatin C, a glucopyranosyl hydroxamate. J. Antibiot. 31, 939-944 (1978).

5 Numajiri, Y., Takahashi, T., Takagi, M., Shin-ya, K. \& Doi, T. Total synthesis of largazole and its biological evaluation. Synlett. 16, 2483-2486 (2008).

6 Dressel, U., Renkawitz, R. \& Baniahmad, A. Promoter specific sensitivity to inhibition of histone deacetylases: implications for hormonal gene control, cellular differentiation and cancer. Anticancer Res. 20, 1017-1022 (2000).

7 Shivashimpi, G. M. et al. Molecular design of histone deacetylase inhibitors by aromatic ring shifting in chlamydocin framework. Bioorg. Med. Chem. 15, 7830-7839 (2007).

8 Yoshida, M., Kijima, M., Akita, M. \& Beppu, T. Potent and specific inhibition of mammalian histone deacetylase both in vivo and in vitro by trichostatin A. J. Biol. Chem. 265, 17174-17179 (1990).

9 Furumai, R., Komatsu, Y., Nishino, N., Khochbin, S., Yoshida, M. \& Horinouchi, S. Potent histone deacetylase inhibitors built from trichostatin $A$ and cyclic tetrapeptide antibiotics including trapoxin. Proc. Natl Acad. Sci. USA 98, 87-92 (2001).

10 Valenzuela-Fernández, A., Cabrero, J. R., Serrador, J. M. \& Sánchez-Madrid, F. HDAC6: a key regulator of cytoskeleton, cell migration and cell-cell interactions. Trends Cell Biol. 18, 291-297 (2008).

11 Rodriguez-Gonzalez, A. et al. Role of the aggresome pathway in cancer: targeting histone deacetylase 6-dependent protein degradation. Cancer Res. 68, 2557-2560 (2008).

12 Matthias, P., Yoshida, M. \& Khochbin, S. HDAC6 a new cellular stress surveillance factor. Cell Cycle 7, 7-10 (2008). 